\title{
Industry, Technological Progress and Development: The Case of Southeast Asia
}

\author{
Manoel Goncalves Rodrigues ${ }^{*}$, Fernando Jose Pereira da Costa ${ }^{2}$ \\ ${ }^{1}$ Researcher at the Research and Extension Directorate Universidade Estácio de SA. \\ 2Independent Researcher.
}

*Corresponding Author Email: manoel.grodrigues@gmail.com

Abstract: Asian countries as Singapore, South Korea, Singapore, Taiwan, China, Vietnam, Malaysia, among others in the Southeast Asia and East Asia have been implementing industrial projects, which are accompanied by a clear process of progress and training human capital in terms of technology and innovation. These countries opted for development processes with a significant degree of direct or indirect state action, with strong investments in education and technology and innovation. This whole process would eventually promote an upgrade of these countries in terms of the system-world economy.

Keyword: Asia, Technology, Innovation.

$\begin{array}{lll}\text { Article Received: } 01 \text { Oct. } 2020 & \text { Revised: } 12 \text { Oct. } 2020 & \text { Accepted: } 23 \text { Oct. } 2020\end{array}$

\section{Introduction}

The developing country of its economy condition is marked by the relative position of each economy in terms of the international hierarchical structure. This, in turn, arises in the scope of the world-system capitalist economy, manifesting itself as a result of the International Division of Labor (IDL), also known as the International Division of Labor and Production (IDLP), as well as its own insertion in terms of the world economy.

The rise of certain countries in developing countries will only succeed with the establishment of a modern, competitive and competitive industrial sector in relation to its global counterparts, in addition to a technological base that supports production, competitiveness and modernization and a cutting-edge educational sector.

The analysis of the relatively recent experiences in terms of industrialization and development, as were (and are) those called as the Asian Tigers, shows that these countries have prioritized clear training strategies, promoting the technological upgrade of clearly peripheral countries or post-colonial. In reality, overcoming the delay implied a clear commitment to technological development, innovation and knowledge as factors that allow for increased productivity gains and strong growth in competitiveness. This is clearly the way forward for the developing countries that seek to overcome their interaction subordinated to the world economy and their industrial fabric, a potential source of innovation and technological training. Countries such as Singapore, South Korea or Taiwan, for instance, have gone through similar experiences of industrialization/training and modernization, skipping stages in their development trajectory, overcoming the backward and reaching prominent positions in the world-economy level, also promoting the achievement of enviable levels regarding indicators related to economic and social development.

\section{Asian Industrialization in the Context of the System-World Economy}

In the words of Wallenstein [1] and Arrigui [2], the relative position of each economy in terms of the hierarchical structure in the context of the world economy, defines the peripheral and semi peripheral condition, which is marked by the relative position of each country in terms of the international hierarchical structure, which manifests itself as a consequence of the IDL/IDLP. The analysis of East Asian economies, mainly 
China and the Asian Tigers (especially South Korea and Taiwan), shows that these countries have prioritized clear training strategies, promoting the technological upgrade of clearly post-colonial countries. The fact is that overcoming the delay implied a clear commitment to technological development, innovation and knowledge as factors that make it possible to increase productivity gains and the strong growth in competitiveness.

The trajectory historically followed by Asian economies points to a system of anti-liberal economic organization, contrary to liberalindividualism and with a strong state component to support (in) directly industrialization, training and innovation. This, however, occurred in other historical moments and contexts, if we consider a slightly more careful analysis in terms of the compared experiences of industrialization and development.

The analysis of the historical experiences of industrialization and development (Germany and Japan) and of the relatively recent cases, as were (and are) the cases of Asian Tigers (mainly that of South Korea and Taiwan) shows that these countries prioritized clear training strategies, following guidelines defined by government agencies specifically oriented to promoting amd fostering development. Thus, we have the successful national-industrializing experiences of lagging economies, while in the second we have the upgrade of clearly peripheral or post-colonial countries.

In both situations, however, overcoming the delay implied a clear commitment to technological development and knowledge as factors that allow for increased productivity gains and strong growth in competitiveness. The Asian Tigers are establishing themselves as industrial and technological bases; the New Tigers (like Malaysia and Vietnam, for example) seem to follow their trail; India asserts itself as an industrial and technological power, notably with regard to Information and Communication Technologies (ICT); Japan, despite the relatively weak performance of its economy, stands out financially, industrially and technologically notably in terms of innovation, and also as a major exporter of capital and promoter of direct investments abroad, many of them in the Asian space itself, as Adda [3] well records, when he analyzes the predominantly regional nature of Japanese transnational companies that promote foreign direct investments.

\section{Technological Delay and Evolution in the Developing Countries}

According to what is recorded by Feldmann [4], technology plays a crucial role in terms of the performance and competitiveness of companies, as well as economies. Therefore, there is a great possibility for companies and countries to compensate for the scarcity of factors and their weaknesses through the development of new products and processes. These, in turn, are obtained through technology.

In fact, technology would put the level of importance of the factors of production considered essential by traditional economic analysis in relative terms and the classic comparative advantages (low wages, abundance of raw materials, cheap capital and large domestic markets) were questioned or relativized by advances and technological innovations simultaneously driven possible by the said globalization process.

The new paradigm is based on innovation, that is, on strong investments in Research \& Development (R\&D) and Research, Development \& Innovation (RD\&I). In fact, the New Industrialized Countries in Asia (NICA) already have relevant initiatives in terms of R\&D and RD\&I, already constituting major providers in terms of scientific and technological knowledge. On the other hand, by way of comparison and according to what Feldmann [4] points out, there is also a disproportion between the economic weight of Latin America and the Caribbean and the efforts in S\&T, both in terms of resources applied in R\&D, and in terms of the number of scientific publications and patents deposited in the United States of America.

On the other hand, Latin America and the Caribbean perform clearly better in scientific activities than in technological activities. Finally, the region shows a predominance of imported technologies, which leads to a limited articulation at the level of the binomial «Science/Technology». In addition, if the economic development of some Asian countries (especially South Korea and Taiwan) is compared with the progress of Latin America and the Caribbean in the 
1980s, there are decisive aspects to explain the enormous growth of Asian economies (notably Asian Tigers) in view of the stagnation of Latin American and Caribbean economies during that decade. In reality, the continent had five shortcomings when compared to Asia's thriving economies.

These deficiencies would be as follows: the presence of a deteriorated educational system with low training of engineers; there was a lot of technology transfer, but a low absorption capacity due to the small investment of local companies in R\&D; existence of a weak S\&T infrastructure; a significant delay in the development of telecommunications; no emphasis on the development of electronic products and the weak link and articulation "University/Company». On the other hand, the so-called globalization process in economic, financial and political terms, for instance, is composed of secondary actors, which at least conditions it as an analyticalconceptual category.

Therefore, it would be necessary to consider the theoretical and conceptual construct of the geopolitics of information and knowledge and its implications in terms of development strategies, which are mainly related to inequalities in relation to the capacity for innovation and also learning, in accordance with the new forms of appropriation of strategic knowledge and also in view of the new requirements for development policies.

The fact is that it is clear that those countries need to rise to more relevant positions with regard to scientific and technological knowledge, in order to break the bonds of dependence, to train themselves from the scientific/technological point of view and to become become creators of knowledge, considered here in its broad sense (generation, production, ownership and management), especially in relation to scientific-technical knowledge.

However, despite the maintenance, at least in terms of the short and medium term, of the situation of coincidences of hegemonies as economic, industrial and technological, there would already be some transformations in order to mitigate the situation of concentration with regard to scientifictechnical knowledge. Many of these transformations are already detectable in
Asia, in a clear movement of opposition to the concentration of the spatial dynamics of the scientific and technological development process in the hierarchical context of the world economy.

\section{The East Asian Emergency}

The scientific-technical development process occurred more concentrated in a few countries, mainly in the area of the Triad (United States of America - Europe - Japan), while the contributions in terms of scientific development were diversified, with the emergence of good S \& T indicators - growth of publications, for example - at the level of developing countries.

Among these, the highlight is the rapid advance recorded by Asian countries, especially the accelerated expansion of China. Before it, the Asian Tigers (South Korea, Taiwan and Singapore), from their respective industrialization projects, reached quite significant levels in terms of technological innovation/training and in terms of scientific and technical progress.

As a result, the expansion of technical and scientific knowledge in Asia has been reducing the huge gap between the hegemon (the United States of America) and a large part of the developing areas with regard to the production of scientific knowledge and technological. One of the most important aspects of the last three decades of the 20th century and the beginning of the 21 st century has to do with the emergence of Asian countries especially those in Southeast Asia in the context of the world economy.

Firstly, it is necessary to mention the socalled Asian Tigers or the Four Asian Dragons, as Bustelo calls them [5], which also uses the denomination of New Industrialized Countries in Asia (NICA), to refer to the cases of South Korea, Taiwan, Hong Kong and Singapore, whose economies have become leaders in economic growth, with expansion rates that have surpassed those of Japan itself.

It should be noted that the investment was financed with domestic resources, being stimulated by an increasing opening to trade international and also through an entire order of fundamental changes in terms of fiscal, financial and institutional. However, despite the strong promotion of exports and 
the clear incentive to private initiative, the NICA, at no time, followed a model that was guided by economic liberalism. However, in the opinion of some authors and experts, the developmental reality of the NICA would be much closer to being unveiled by the focus of the State promoting the acceleration of the industrialization process and technological catching up (revisionist version). As such, state intervention was much more important than in the late industrialized economies of the 19 th century.

In South Korea and Taiwan, in the early 60s of the last century, despite the low wages, there was an enormous competitive incapacity. In other words, even if it worked correctly, the market, by itself, was not able to foster industrialization. Therefore, state intervention did not harmonize with the market, but rather enabled an active industrialization strategy.

Otherwise, it should be noted that the role assumed by the State, within the scope of the NICA, would far exceed that of the Latin American national-developentalist State, since the state action had here an eminent strategic role, that is, through strategic planning (the State as a strategist), the state sphere outlined, configured and implemented the national strategy of industrialization, technological training and development of these countries.

In fact, the experience of East Asian countries, as recorded by Masiero [6], in training and management of human resources, as well as in the absence of strong disparities, in terms of salary gains, between extreme hierarchical-professional levels as it seems to be the case of Japan, in education and learning mainly in the technological areas, in innovation of technologies, as well as in training, demonstrate that these countries are forming a large army of qualified professionals to work in the international market, meet the needs of large organizations, as well as small and mediumsized companies.

This is clear in the case of South Korea, but also in China, which between 1999 and 2005 increased the number of students enrolled in higher education by more than triple. In fact, these countries are training highly qualified labor for large corporations operating in the world market, whether transnational or indigenous, which, due to the increasing internationalization of R\&D activities, demand highly qualified labor. On the other hand, South Korean companies assimilated the labor force formed in the United States of America and a native of that country. As far as China is concerned, it has opened up to transnational corporations, while ensuring the transfer of technology and the local development of cutting edge technologies for part of these companies, in addition to the internationalization of Chinese companies.

It is in this context that the so-called Asian Corridor is formed, as a result of the expansion of China and India and the interconnection of the countries of Northeast Asia with these two economies and Southeast Asia, with the establishment of agreements that go beyond Asian borders (as Mexico, for example), constituting a large community of producing companies in East Asia.

In effect, new Asian producers and consumers will seek more efficient ways and methodologies in terms of the organization of production, such as just-in-time or quality control, defining a path towards the continuous improvement of business, management methods , the organizational and institutional configurations, as well as the various cooperation agreements in different segments of activity.

As recorded by Bresser-Pereira [7], in the same way that the 20 th century was marked by North American hegemony, everything seems to point out that the 21st century is the century of Asia (and not only of China), already being seen, today, to the displacement of the world economic axis that, for some centuries was located in Europe, becoming, in the 20th century, located in the United States of America. However, if capitalism advances, in all parts of the world, generating wealth and inequality, it is worth noting that nowhere else in the world is it as dynamic as in Asia.

To this end, the community and holistic culture of Asian countries collaborated greatly, extremely different from Western references (individualism and liberalism), configuring techno bureaucratic capitalism, with the State assuming a decisive role in the formulation/implementation of the strategy. The methods of coordination and management of companies, contrary to what occurs in the Western world, are guided by cooperation and not by competition, 
relegating individualism to the background. The emergence of Asia and not just its East or Southeast regions, is one of the most important facts to mark the end of the 20th century and the beginning of the 21st century. Asian economies, in fact, quickly reached important stages in terms of their processes of industrialization and dynamic integration in the context of the world economy.

Unlike Western countries, Asian countries did not allow themselves to be led by the siren call of liberalism, instead opting for a strong State pointed out intervention, regulator, coordinator and strategist, for targeted public policies such as in education, for example, for training technology, integrated industrialization processes and dynamic integration in the world economy. From the dynamic, synergistic and virtuous interaction between the State and companies such as the cases of Japan, South Korea and China, for example, industrialized, technologically advanced and strongly competitive economies emerged.

It seems that the formation of a great Asian system is outlined today, in which the synergies made possible by it will convert the Pacific into the economic axis of the 21st Century. However, the conformation and arrangements of diverse order that will characterize such a system are not yet completely defined, mainly with the possible rise of a hegemon, within the scope of that system or even considering its absence.

Technological progress and knowledge creation and management in the broader case of developing countries, cannot be thought outside the domain of public policies and lack a strategic vision towards the technological issue, notably in what concerns technological training. The break with the academic-traditionalist view regarding the generation of knowledge and technological training requires a dynamic-systemic interaction of an institutional nature that brings together universities, university technological centers, public technological institutes and companies, notably from the industrial sector.

This presupposes an active, dynamic and strategic State, which functions as an aggregator, promoter and facilitator of all these institutions and which promotes, through direct/indirect instruments, national technological training. Indigenous technological training involves the existence of innovative national companies. In the case of South Korea, it was possible to ensure the interactive relationship "Companies/National Technology" by the existence of chaebols and by the government/business effort with regard to the use of national technology.

In the case of Brazil, for example, where the presence of transnational companies is relative strong, with intense use of imported and licensed technology, including by Brazilian companies, which end up acting as true disseminators and multipliers of external technology, the articulation nationalization/innovation would be a measure of high strategic content.

This initiative could stimulate the installation, in the country, of RD\&I centers of transnational companies and, on the other hand, support research and innovation in national companies. According to Cassiolato [8], with regard to measures to support innovation, despite support for $R \& D$ being a policy mechanism that has been used for a long time, it has changed substantially over the present decade, becoming the most important instrument of industrial policy used by OECD countries.

Most of the time, support was linked to large programs designed and coordinated by States (armaments, aeronautics, computers, etc.). Today, in most OECD countries, direct support for companies' $R \& D$ activities is an industrial policy instrument of more general use. Among the reasons that explain this change are the loss of attractiveness of large programs and the fact that, as they may fall into the category of "market failures", such measures do not violate WTO rules. More importantly, however, the emphasis on measures to support technological innovation by the most advanced countries is closely linked to the development, diffusion and efficient use of new technologies (especially ICT) in the knowledge-based economy.

Thus, in addition to the aforementioned convergence between industrial and technological policies, there is a growing recognition of the importance of innovation and national innovation systems in such countries. It is noteworthy that the emphasis on the focus of the innovation system itself already considers that the innovative process, as well as the policies to stimulate it, cannot 
be seen as isolated elements of their national, sectorial, regional, institutional and organizational contexts. It is not surprising that industrial and technological policies in most advanced countries have played a significant role in accelerating the efficient diffusion of electronic technologies stimulating the emergence of efficient users and the development of producer-user connections - and in the preservation of the main components of national sovereignty, fundamentally the domain and some degree of partial autonomy in critical technologies, particularly in information and communications [8].

In the analysis of new trends influencing policies to promote industrial and technological development, it is emphasized that, in the current era, knowledge is the main resource and learning is the central process. This is the motto of the close relationship between new industrial and technological policies and the knowledge economy. In the analysis of new trends influencing policies to promote industrial and technological development, it is emphasized that, in the current era, knowledge is the main resource and learning is the central process.

\section{Conclusions}

Technological progress is, simultaneously, one of the major driving factors and perhaps the main manifestation of the progress registered in terms of the degree of development of the productive forces. The advanced capitalist countries are clearly hegemonic in terms of promoting technical progress and technological advancement in their respective economies, endowing themselves with productive bases mainly industrial ones, modern, advanced and competitive, backed by a major technological base, by a innovative processes.

The binomial «Technology/Innovation» will correspond to a better level regarding the hierarchical-systemic graduation of these countries, which formed their advanced technological bases due to having set up relevant productive-industrial structures, installing sectors with high added value. And with high levels of technological sophistication, almost permanently fueled by a torrent of the innovations. In other words, the binomial «Technology/Innovation» is made possible by the two-way relationship Industry / Technology, which defines the clear interaction between industrialization processes and the possibility of accessing technologies with certain or high levels of sophistication, whether via licensing, or through training as a clear case of developed countries and some developing countries of recent industrialization.

Among these, three cases can be distinguished, namely: those that resorted to foreign investment and licensed technology; those who, using foreign investment and technology licensing, developed their own technologies in certain fields and activities, from national companies and with state support; those who started operating with licensed technologies but started to develop their own technological base based on learning / training.

It becomes necessary to set up an industrial base of a minimally national character and, from there, to promote the technological capacity of that country. Starting from this point, through R\&D and RD\&I efforts, the bases are laid for the achievement of an effective/significant and sustained technological development, with this economy reaching the scale of expanded production and reproduction of technology, in order to stimulate technological progress based on innovation.

In this sense, in the context of the National Development Strategy, the trajectory of that country/economy in terms of technology, technological training and technological development must be configured, in an intimate relationship and intense interaction with the industrial apparatus installed there and in the center of a synergistic-interactive relationship between the spheres of Public Policy respectively related to the industrial area and the technological component [9-14].

\section{References}

1. Wallerstein I (1999) O Capitalismo Histórico seguido de A Civilização Capitalista. Vila Nova de Gaia: Estratégias Criativas.

2. Arrigui G (1997) A ilusão do desenvolvimento. Petrópolis. Vozes.

3. Adda J (2004) As Origens da Globalização da Economia. Barueri. Manole. 
4. Feldmann PR (2010) O atraso tecnológico da América Latina como decorrência de aspectos geográficos e de fatores microeconômicos [Em Linha]. Disponível em

«http://periscopio.bligoo.com.br/content/vie w/910440/America-Latina-Atraso-

tecnologico.html». [Consultado em 08/07/2012]. Periscópio. Educação Tecnológica. Resumo do artigo de 22 páginas.

5. Bustelo (1994) Los cuatro dragones asiáticos: economia, politica y sociedad. Madrid. ESIC.

6. Masiero G (2007) Negócios com Japão, Coréia do Sul e China: Economia, Gestão e Relações com o Brasil. São Paulo. Saraiva.

7. Bresser-Pereira LC (2007) «Prefácio» in Masiero, G. Negócios com Japão, Coréia do Sul e China: Economia, Gestão e Relações com o Brasil. São Pauo. Saraiva.

8. Cassiolato (1999) A Economia do Conhecimento e as Novas Políticas Industriais e Tecnológicas in LASTRES, H. e ALBAZI, S. (orgs.): Informação e Globalização na Era do Conhecimento. Rio de Janeiro. Campus, 314:180-186.

9. Baumgarten M (2007) Geopolítica do conhecimento e da informação: semiperiferia e estratégias de desenvolvimento [Em Linha]. Disponível em «http://www.ibict.br/liinc». [Consultado em 05/07/2012]. Brasília. Ibict. Liinc em Revista, 3(1):17-33.

10. Bustelo (1998) Teorías contemporáneas del desarrollo económico. Madrid. Sintesis.

11. Fiori LF (2020) Estado e Desenvolvimento na América Latina. Rev. econ. contemp. 24-1 Rio de Janeiro 2020 Epub /April 27, $2020 . \quad$ Disponível em: http://dx.doi.org/10.1590/198055272416>. [Consultado em 14/07/2020].

12. Medeiros CA (2016) Estrutura produtiva e crescimento econômico em economias em desenvolvimento. Econ. soc. 253 Campinas. Disponível em: $<$ https://doi.org/10.1590/19823533.2016v25n3art3>. [Consultado em 05;07/2020]

13. medeiros CA (2019) Política Industrial e Divisão Internacional de Trabalho. Brazil. J. Polit. Econ. 39-1, São Paulo. Disponível em: < https://doi.org/10.1590/010135172019-2925>. [Consultado em 10/08/2020].

14. Nicolsky R (2001) Inovação tecnológica industrial e desenvolvimento sustentado. Estratégias para ciência, tecnologia e inovação. Parcerias Estratégicas, $\mathrm{n}^{0} 13$. Brasília. MCT/CGEE, 80-108. 